\title{
Low-iodine diet for the production of severe I deficiency in marmosets (Callithrix jacchus jacchus)
}

\author{
By M. T. MANO, B. J. POTTER, G. B. BELLING AND B. S. HETZEL \\ Division of Human Nutrition, CSIRO Australia, Kintore Avenue, Adelaide, \\ South Australia 5000, Australia
}

(Received 13 February 1985 - Accepted 3 April 1985)

\begin{abstract}
1. A low-iodine diet consisting of maize, peas (Pisum sativum), torula yeast, meat meal, maize oil and added vitamins, minerals and amino acids was given to eight pairs of adult, common cotton-eared marmosets (Callithrix jacchus jacchus). Eight control pairs were given the same diet to which potassium iodate was added. Both groups also received low-I apple and deionized water.

2. The diet provided adequate nutrition, as confirmed by the maintenance of body-weight and good health.

3 . In the I-deficient marmosets the concentration of plasma thyroxine was decreased from $140 \cdot 1 \mathrm{nmol} / 1$ to $22.4 \mathrm{nmol} / \mathrm{l}$ and thyroid-stimulating hormone increased significantly from $1.8 \mathrm{ng} / \mathrm{ml}$ to $9.0 \mathrm{ng} / \mathrm{ml} \mathrm{compared} \mathrm{with}$ control marmosets, thereby indicating severe I deficiency.

4. Compared with newborn offspring from control marmosets, the thyroid glands from the I-deficient offspring showed (a) an increase in weight, (b) a decrease in I content and (c), on histological examination, hyperplasia, hypertrophy and a total absence of colloid material in the follicles.
\end{abstract}

Severe iodine deficiency, associated with high rates of endemic goitre, endemic cretinism and other defects, produces a spectrum of conditions now designated 'I-deficiency disorders' (Hetzel, 1983).

There has been a need to develop animal models to investigate the relation of I deficiency to development (particularly fetal brain development) further and determine the mechanisms involved. In the sheep, severe I deficiency has been shown to cause severe hypothyroidism with brain retardation in the fetus (Potter et al. 1980, 1982). Less striking effects have been observed in the rat (McIntosh et al. 1980).

In the present study, a low-I diet has been produced to assess the effects of severe I deficiency on a non-human primate. The common cotton-eared marmoset (Callithrix jacchus jacchus) was chosen because it is phylogenetically similar to man, relatively easy to handle, inexpensive to house and feed (Grist, 1973; Hearn et al. 1975; McIntosh \& Looker, 1982) and is suitable for teratological research (Poswillo et al. 1972).

\section{MATERIALS AND METHODS \\ Diet}

The formulation of the low-I diet (LID) was based on the rat diet used by McIntosh et al. (1980), modified for the marmosets by the addition of low-I meat meal, vitamins and amino acids (Table 1). The low-I meat meal was specially produced at this laboratory from sheep which were given a diet of low-I maize and pea pollard (husk which surrounds the pea seed but does not include the pod) 3-5 months before slaughter (Potter et al. 1980). Maize and peas (Pisum sativum) were used as the major source of carbohydrate, while the meat meal, torula yeast and peas provided the protein.

The dry components of the LID were thoroughly blended in a dough mixer and subsequently pelleted in a moist state ( $300 \mathrm{~g}$ deionised water $/ \mathrm{kg}$ ) using a meat grinder with a plate of $9 \mathrm{~mm}$ hole size. The pelleted diet was stored frozen $\left(-20^{\circ}\right)$ rather than dried because of the preference by the marmosets for a moist diet and the fact that the process of drying caused oxidation of vitamin $\mathrm{C}$. 
Table 1. Composition of the low-iodine diet given to marmosets (Callithrix jacchus jacchus)

\begin{tabular}{|c|c|c|}
\hline Component & $\begin{array}{l}\text { Contains } \\
\text { (/kg diet) }\end{array}$ & Source \\
\hline Maize & $600 \mathrm{~g}$ & South Queensland, Australia \\
\hline Peas (Pisum sativum) (dried) & $150 \mathrm{~g}$ & South Island, New Zealand \\
\hline Torula yeast (dried) & $100 \mathrm{~g}$ & Sanitarium Health Foods (Australia) \\
\hline Meat meal (dried) & $100 \mathrm{~g}$ & From low-I sheep (Potter et al. 1980) \\
\hline Maize oil & $15 \mathrm{~g}$ & Nuttelex Food Products (Australia) \\
\hline $\mathrm{CaCO}_{3}$ & $15 \mathrm{~g}^{*}$ & - \\
\hline $\mathrm{NaCl}$ & $5 \mathrm{~g}^{*}$ & - \\
\hline $\mathrm{CoCl} .6 \mathrm{H}_{2} \mathrm{O}$ & 30 mg* & - \\
\hline $\mathrm{CuSO}_{4} \cdot 5 \mathrm{H}_{2} \mathrm{O}$ & 39 mg* & - \\
\hline $\mathrm{MnSO}_{4} \cdot \mathrm{H}_{2} \mathrm{O}$ & $156 \mathrm{mg}^{*}$ & - \\
\hline $\mathrm{ZnSO}_{4} \cdot 7 \mathrm{H}_{2} \mathrm{O}$ & $110 \mathrm{mg}^{*}$ & - \\
\hline $\mathrm{FeSO}_{4}$ & $300 \mathrm{mg}^{*}$ & - \\
\hline & & Sigma catalogue no. \\
\hline Choline chloride & $1250 \mathrm{mg}^{*}$ & C1879 \\
\hline L-Lysine monohydrochloride & $1200 \mathrm{mg}$ & L5626 \\
\hline L-Methionine & $850 \mathrm{mg}$ & M9625 \\
\hline Vitamin C (ascorbic acid) & $3000 \mathrm{mg}$ & A7506 \\
\hline $\begin{array}{l}\text { Vitamin A (retinol palmitate } \\
\text { trans type IV) }\end{array}$ & $18000 \mu \mathrm{g}^{\dagger}$ & $\mathrm{R} 3375$ \\
\hline Vitamin $\mathrm{D}_{3}$ (cholecalciferol) & $280 \mu \mathrm{g} \dagger$ & C9756- - \\
\hline $\begin{array}{l}\text { Vitamin } E \text { (D- } \alpha \text {-tocopherol } \\
\text { acetate type III) }\end{array}$ & $24300 \mu \mathrm{g} \dagger$ & T3001 \\
\hline Vitamin $\mathbf{K}_{3}$ (menadione) & $3000 \mu \mathrm{g}$ & M5750 \\
\hline Vitamin $B_{12}$ (cyanocobalamin) & $40 \mu \mathrm{g}$ & V2876 \\
\hline $\begin{array}{l}\text { Vitamin } B_{1} \text { (thiamin } \\
\text { hydrochloride) }\end{array}$ & $27000 \mu \mathrm{g}$ & $\mathrm{T} 4625$ \\
\hline Vitamin $B_{2}$ (riboflavin) & $18000 \mu \mathrm{g}$ & R4500 \\
\hline $\begin{array}{l}\text { Vitamin } B_{6} \text { (pyridoxine } \\
\text { monohydrochloride) }\end{array}$ & $13000 \mu \mathrm{g}$ & P9755 \\
\hline D-Pantothenic acid & $40000 \mu \mathrm{g}$ & P2250 \\
\hline Folic acid & $10000 \mu \mathrm{g}$ & F7876 \\
\hline D-Biotin & $500 \mu \mathrm{g}$ & B4501 \\
\hline Niacin (nicotinic acid) & $78000 \mu \mathrm{g}$ & N4126 \\
\hline
\end{tabular}

* Dissolved in $200 \mathrm{ml}$ deionized water to moisten diet for pelleting.

+ Dissolved in the $15 \mathrm{~g}$ maize oil.

Each marmoset was offered $30 \mathrm{~g} \mathrm{diet} / \mathrm{d}$ but consumed about $18 \mathrm{~g}$ in addition to $8 \mathrm{~g}$ apple. The I content of the diet and apple was 12.1 (SE 1.4) and 11.0 (SE 1.0) $\mu \mathrm{g} \mathrm{I} / \mathrm{kg}$ (wet weight) respectively, giving an I intake of $0.3 \mu \mathrm{g} / \mathrm{d}$. Control animals were given the same diet to which potassium iodate was added to give 420 (SE 21) $\mu \mathrm{g} \mathrm{I} / \mathrm{kg}$ (wet weight) of high-I diet (HID) or an intake of approximately $7.6 \mu \mathrm{g} \mathrm{I} / \mathrm{d}$.

The animals were supplied with deionized water ad lib.

\section{Animals}

Sixteen pairs of marmosets between the ages of 14 and 24 months were divided into two groups, one being given the LID and the other the HID. The marmosets were kept in pairs of opposite sex in aluminium cages (North Kent Plastics Ltd, Home Gardens, Dartford, Kent, UK) in a room maintained at $26^{\circ}$ and $50 \%$ humidity and provided with $12 \mathrm{~h}$ fluorescent lighting and $45 \mathrm{~min}$ u.v. light/d (Poswillo et al. 1972; McIntosh \& Looker, 1982).

Body-weight was measured weekly and blood samples were withdrawn from the femoral 
vein (Hearn et al. 1975) into dry heparinized tubes every 2 months to assess the onset and progress of I deficiency by the plasma levels of thyroxine $\left(\mathrm{T}_{4}\right)$ and thyroid-stimulating hormone (TSH).

\section{I analysis}

I in the diet and thyroid tissue was measured using alkaline ashing (Foss et al. 1960) suitably modified, followed by a spectrophotometric determination based on the catalytic effect of I on the oxidation-reduction reaction between Ce(IV) and As(III) (Potter et al. 1980; Belling, 1982).

\section{$T_{4}$ and TSH determination}

Plasma obtained by centrifugation of heparinized blood was used for determination of $T_{4}$ (Potter et al. 1980) and TSH by a modification of the method of Patel et al. (1971) using human TSH antibody and the International Reference Preparation 68/38, National Institute of Medical Research, Mill Hill, London, UK.

\section{Thyroid gland}

To allow further investigations to be made on the two groups of marmosets, thyroid assessment was made on their newborn progeny (gestational age $150 \mathrm{~d}$ ).

The newborn offspring were killed with an overdose of the steroid anaesthetic Saffan obtained from Glaxo Laboratories Ltd, Greenford, Middlesex, UK (Phillips \& Grist, 1975) before the thyroid glands were removed and weighed. Half the gland was frozen $\left(-20^{\circ}\right)$ for I determination and half fixed in neutral buffered formaline $(100 \mathrm{ml} / \mathrm{l})$ for histology. After embedding in paraffin, the fixed thyroid tissue was cut into $6-\mu \mathrm{m}$ sections and stained with haemotoxylin and eosin for examination by light microscopy.

\section{Statistics}

The Student's $t$ test was used to assess significance.

\section{RESULTS}

\section{Body-weight and general condition}

After eating the diet for 6 months the marmosets were I deficient and yet maintained their condition. In fact at the end of that period their body-weights remained slightly more than that of the controls (Fig. 1). The animals exhibited normal activity with no apparent change in their behaviour.

\section{$T_{4}$ and TSH}

Plasma $T_{4}$ was used to monitor the progress of I deficiency and, as shown in Fig. 2, $T_{4}$ levels declined rapidly in the first 9 months to a value of 22.4 (SE $2 \cdot 1$ ) nmol/1, being significantly lower $(P<0.001)$ than $140 \cdot 1$ (SE 7.7) $\mathrm{nmol} / \mathrm{l}$ for the controls.

Plasma TSH values for I-deficient and control marmosets were 9.0 (SE 1.6$) \mathrm{ng} / \mathrm{ml}$ and $1.8($ SE 0.2$) \mathrm{ng} / \mathrm{ml}$ respectively $(P<0.001)$ but the values for both treatment groups were lower than might be expected. This is possibly due to a low cross-reaction of marmoset TSH with the human antibody used in the radioimmunoassay.

\section{Thyroid gland}

Histology of the thyroid gland from I-deficient newborn offspring revealed obvious hyperplasia, hypertrophy and a complete absence of colloid material in the follicles (Plate 1) in comparison with the offspring of the control group.

Highly-significant effects of I deficiency on thyroid weight and I content of newborn marmosets are shown in Table 2. 


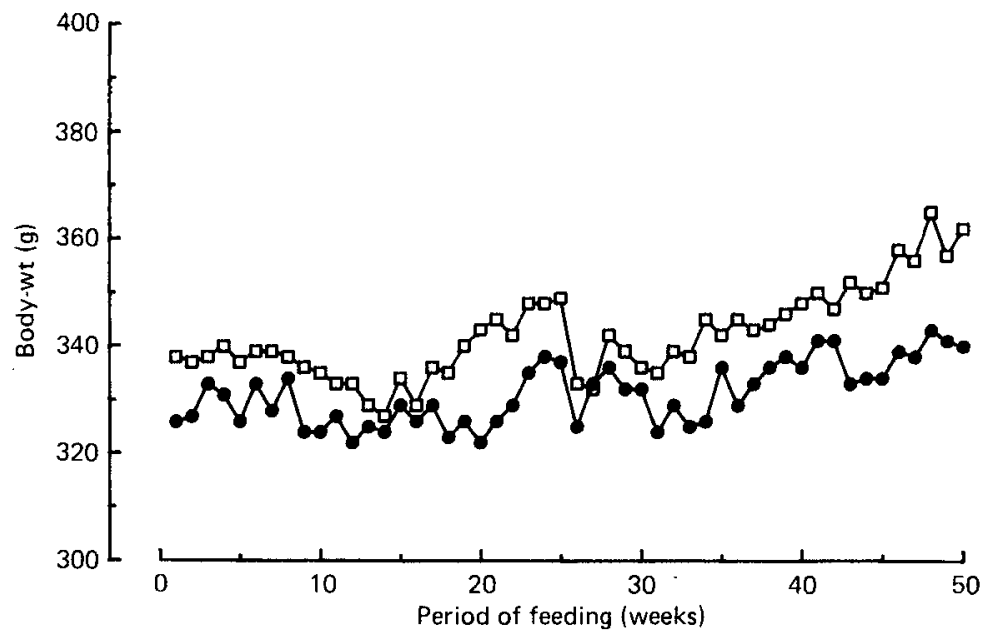

Fig. 1. Body-weights of marmosets (Callithrix jacchus jacchus) given an iodine-deficient ( $\square$ ) or control (O) diet for 50 weeks.

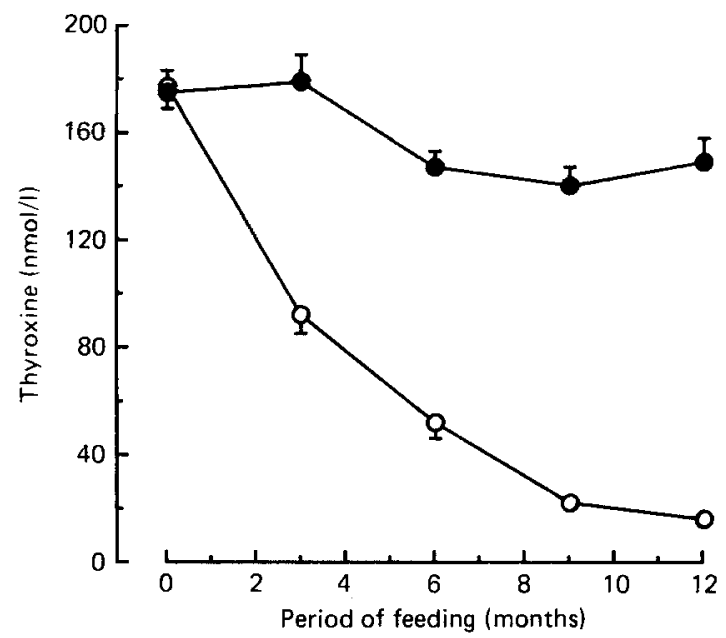

Fig. 2. The decline observed in plasma thyroxine levels (nmol/l) of iodine-deficient $(O)$ compared with control (O) marmosets (Callithrix jacchus jacchus) during the first 12 months of diet consumption. Points are means with their standard errors represented by vertical bars.

Table 2. Weight and iodine content of the thyroid glands from newborn marmosets (Callithrix jacchus jacchus)

(Mean values with their standard errors)

\begin{tabular}{|c|c|c|c|c|c|}
\hline & \multirow{2}{*}{$\begin{array}{c}\text { No. of } \\
\text { observations }\end{array}$} & \multicolumn{2}{|c|}{ Wt (mg) } & \multicolumn{2}{|c|}{ I content (ng) } \\
\hline & & Mean & $\mathrm{SE}$ & Mean & SE \\
\hline Control & 6 & $9 \cdot 6$ & 0.6 & 14780 & 1920 \\
\hline I-deficient & 11 & $50 \cdot 6$ & $4 \cdot 8$ & 57 & 6 \\
\hline \multicolumn{2}{|c|}{$\begin{array}{l}\text { Statistical significance of } \\
\text { difference between treatments }\end{array}$} & \multicolumn{2}{|c|}{$P<0.001$} & \multicolumn{2}{|c|}{$P<0.001$} \\
\hline
\end{tabular}




\section{DISCUSSION}

The diet described in the present paper achieved severe I deficiency in the marmoset and yet normal body-weight (Fig. 1) and good health were maintained. 'Wasting marmoset syndrome', believed to be of dietary origin, was not evident at any stage, probably due to a sustained adequate protein intake which was achieved by limiting the amount of soft foods such as banana and apple which the marmosets would consume in preference to the more nutritious diet pellets (Shimwell et al. 1979).

The success of the diet was achieved largely by enhancing the palatability with the addition of low-I meat meal prepared from sheep given a LID (Potter et al. 1980) although any source of low-I meat protein should be acceptable provided it remains palatable to the marmoset. The advantages of meat meal are emphasized by the observations of McIntosh \& Looker (1982) that marmosets prefer a diet with a high meat content and the fact that they require a high-protein intake (King, 1978; Shimwell et al. 1979). In addition, feeding the diet as a soft moist pellet $(300 \mathrm{~g}$ water $/ \mathrm{kg}$ ) was more acceptable to the marmosets than a hard, dry pellet. This agrees with the observations of Wirth \& Buselmaier (1982) that consumption was improved when the diet was softened with water.

The degree of I deficiency achieved with this diet is clearly demonstrated by the significant reduction in plasma $\mathrm{T}_{4}$ and increased plasma TSH. Further evidence of severe I deficiency can be seen from the significant effects on the thyroid gland of newborn offspring, as shown by an increase in weight, a decrease in I content (Table 2) and histologically by a total absence of colloid material in the follicles (Plate 1).

In conclusion, our results show that with this diet formulation it is feasible to study the effects of I deficiency and, in particular, the nutritional stress it imposes on the fetus, in a non-human primate. This kind of study can be related to man, in whom some investigations of I deficiency are unacceptable for ethical reasons, and dietary regimens difficult to control.

The authors gratefully acknowledge the technical assistance of D. M. Martin for the $T_{4}$ analyses, F. J. Fraser for the histology, J. W. Looker for the care and feeding of the animals and S. Stuart (Queen Elizabeth Hospital, Woodville, South Australia) for the TSH analyses. They are indebted also to Dr G. H. McIntosh for his interest and helpful advice.

\section{REFERENCES}

Belling, G. B. (1982). Determination of Iodine, pp. 1-14. Adelaide: CSIRO Division of Human Nutrition.

Foss, O. P., Hankes, L. V. \& van Slyke, D. D. (1960). Clinica Chimica Acta 5, 301-326.

Grist, S. M. (1973). Journal of the Institute of Animal Technicians 27, 1-7.

Hearn, J. P., Lunn, S. F., Burden, F. J. \& Pilcher, M. M. (1975). Laboratory Animals 9, 135-137.

Hetzel, B. S. (1983). Lancet ii, 1126-1129.

King, G. J. (1978). British Journal of Nutrition 40, 55-62.

McIntosh, G. H., Jones, G. B., Howard, D. H., Belling, G. B., Potter, B. J. \& Hetzel, B. S. (1980). Australian Journal of Biological Sciences 33, 205-211.

McIntosh, G. H. \& Looker, J. W. (1982). Laboratory Animal Science 32, 677-679.

Patel, Y. C., Burger, H. G. \& Hudson, B. (1971). Journal of Clinical Endocrinology 33, 768-774.

Phillips, I. R. \& Grist, S. M. (1975). Laboratory Animals 9, 57-60.

Poswillo, D. E., Hamilton, W. J. \& Sopher, D. (1972). Nature 239, 460-462.

Potter, B. J., Jones, G. B., Buckley, R. A., Belling, G. B., McIntosh, G. H. \& Hetzel, B. S. (1980). Australian Journal of Biological Sciences 33, 53-61.

Potter, B. J., Mano, M. T., Belling, G. B., McIntosh, G. H., Hua, C., Cragg, B. G., Marshall J., Wellby, M. L. \&

Hetzel, B. S. (1982). Neuropathology and Applied Neurobiology 8, 303-313.

Shimwell, M., Warrington B. F. \& Fowler, J. S. L. (1979). Laboratory Animals 13, 139-142.

Wirth, H. \& Buselmaier, W. (1982). Laboratory Animals 16, 175-181. 
EXPLANATION OF PLATE

Thyroid tissue of newborn marmosets (Callithrix jacchus jacchus) showing a total absence of colloid material (col) in the follicles of $(a)$ the iodine-deficient gland compared with $(b)$ the control gland. 

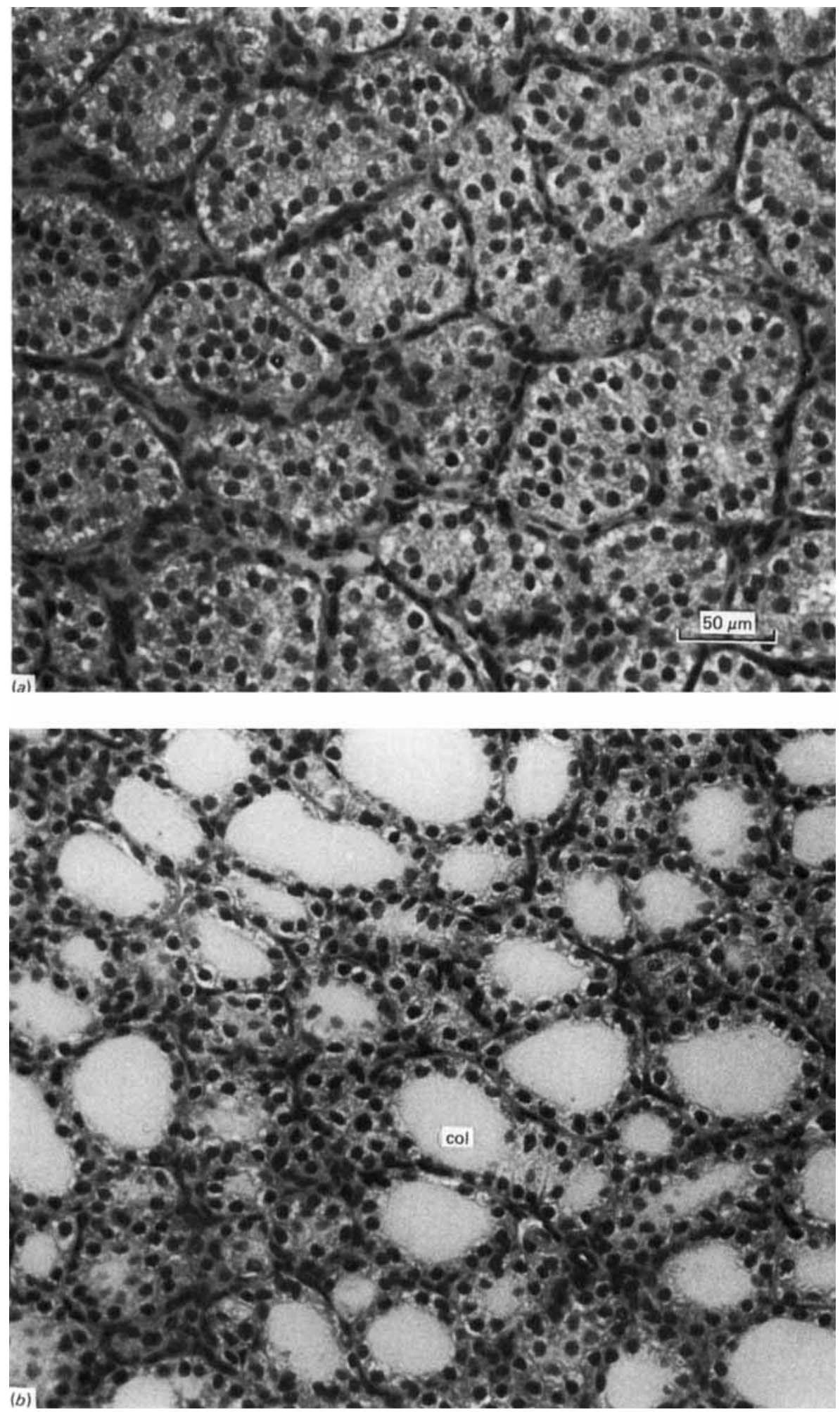